\title{
Catalytic Properties of Pd Modified Cu/SAPO-34 for NO $x$ Removal from Diesel Engine
}

\author{
J. C. Wang, ${ }^{1}$ H. Qiao, ${ }^{1}$ L. N. Han, ${ }^{1,2}$ Y. Q. Zuo, ${ }^{1}$ L. P. Chang, ${ }^{1}$ W. R. Bao, ${ }^{1}$ and G. Feng ${ }^{3}$ \\ ${ }^{1}$ Key Laboratory of Coal Science and Technology, Ministry of Education and Shanxi Province, Taiyuan University of Technology, \\ Taiyuan, Shanxi 030024, China \\ ${ }^{2}$ School of Materials Science and Engineering, Taiyuan University of Technology, Taiyuan, Shanxi 030024, China \\ ${ }^{3}$ Shanghai Research Institute of Petrochemical Technology SINOPEC, Shanghai 201208, China
}

Correspondence should be addressed to W. R. Bao; baoweiren@tyut.edu.cn and G. Feng; fengg.sshy@sinopec.com

Received 20 November 2013; Accepted 12 December 2013

Academic Editor: Wen Zeng

Copyright (C) 2013 J. C. Wang et al. This is an open access article distributed under the Creative Commons Attribution License, which permits unrestricted use, distribution, and reproduction in any medium, provided the original work is properly cited.

The Cu/SAPO-34 catalysts with different $\mathrm{Cu}$ contents were prepared by in situ hydrothermal synthesis. The selected Cu/SAPO34 was modified by impregnating $1 \mathrm{wt} \% \mathrm{Pd}\left(\mathrm{NO}_{3}\right)_{3}$. The morphology and structure of the samples were characterized via XRD and SEM techniques. The effects of $\mathrm{Cu}$ contents and the Pd modification on the de- $\mathrm{NO}_{x}$ activity of the samples were investigated through the selective catalytic reduction by $\mathrm{C}_{3} \mathrm{H}_{6}$ and $\mathrm{NH}_{3}$. The $\mathrm{Cu}$ contents do not change the skeleton structure of the SAPO-34 crystalline and the $\mathrm{Cu} / \mathrm{SAPO}-34$ catalysts with $\mathrm{Cu} / \mathrm{Si}$ ratios of $0.05,0.1$, and 0.2 have better de- $\mathrm{NO}_{x}$ activity than other catalysts. The addition of Pd can improve the de- $\mathrm{NO}_{x}$ activity of the $\mathrm{Cu} / \mathrm{SAPO}-34$ catalysts. The maximum of NO conversion of samples with $\mathrm{Pd}$ could reach $90 \%$. Besides, the effect of aging treatment for $\mathrm{Cu} / \mathrm{SAPO}-34$ catalysts with and without Pd on the de- $\mathrm{NO}_{x}$ activity was also investigated. The results indicated that the $\mathrm{Cu} / \mathrm{SAPO}-34$ catalysts modified by $\mathrm{Pd}$ have better antiaging performance than raw samples.

\section{Introduction}

$\mathrm{NO}_{x}$ can react with hydrocarbons (HC) and produce photochemical smog, which is increasingly highlighted and to be concerned about [1-3]. Selective catalytic reduction (SCR) is an effective method for controlling the emission of $\mathrm{NO}_{x}$, which has already been used in industry [4-6]. The development of high efficiency catalyst, as the key technology of SCR, has received more and more concerns [7]. Depending on high thermal and hydrothermal stability [8-11], metalSAPO-34 has a broad application prospect. The proper pore structure makes it exhibit excellent properties in the region of diesel engine exhaust purification [12]. As is known to all, the dispersion of the active sites is closely related to the metal loading for the supported catalysts. When the loading amount of metal is much too high, it could aggregate easily during the calcination process. Therefore, there should be a suitable amount of active components, neither too much nor too little, loading on the support. Meunier et al. [13] found that a maximum $\mathrm{NO}_{x}$ conversion could be available on $\mathrm{Ag} / \mathrm{Al}_{2} \mathrm{O}_{3}$ when the $\mathrm{Ag}$ loading was $1 \%$; however, the conversion decreased obviously when Ag loading was $2 \%$. Horiuchi et al. [14] reported that the highest activity could be achieved over $\mathrm{Co} / \mathrm{Al}_{2} \mathrm{O}_{3}$ when Co loading was $0.5 \%$. These results indicate that the active metal content of the catalysts is very important for the catalytic activity.

As a kind of low-cost active constituent for the SCR of $\mathrm{NO}, \mathrm{Cu}$ has drawn the attentions of many researchers $[15,16]$, but diesel exhaust is often at high temperatures $\left(>650^{\circ} \mathrm{C}\right)$ and the antiaging capacity is required $[17,18]$. Morever, as one of the noble metals, $\mathrm{Pd}$ is a promising candidate for HC-SCR in excess oxygen [19-21]. In this paper, a series of Cu/SAPO-34 catalysts were prepared by hydrothermal synthesis. The effect of $\mathrm{Cu}$ content and $\mathrm{Pd}$ modifying on the de- $\mathrm{NO}_{x}$ activity were investigated. The morphology and structure of the samples were characterized using XRD and SEM. In addition, the influence of the aging treatment of the prepared catalysts was studied. 


\section{Experimental}

2.1. Preparation of Catalysts. The Cu/SAPO-34 catalysts with different $\mathrm{Cu}$ contents were prepared by insitu hydrothermal synthesis, and the details were as follows: $\mathrm{CuO}, \mathrm{H}_{3} \mathrm{PO}_{4}$, $\mathrm{Al}(\mathrm{OH})_{3}$, and silica gel were used as the sources of $\mathrm{Cu}, \mathrm{P}, \mathrm{Al}$, and $\mathrm{Si}$, respectively. Morpholine $\left(\mathrm{C}_{4} \mathrm{H}_{9} \mathrm{NO}\right)$ was selected as the template. The crystallization gel was prepared according to the mole ratio of $n \mathrm{CuO}: 0.2 \mathrm{SiO}_{2}: 0.92 \mathrm{Al}(\mathrm{OH})_{3}: 0.9$ $\mathrm{H}_{3} \mathrm{PO}_{4}: 1.25 \mathrm{C}_{4} \mathrm{H}_{9} \mathrm{NO}: 50 \mathrm{H}_{2} \mathrm{O}: 0.01 \mathrm{HF}(n=0,0.005,0.01$, $0.02,0.04$, and 0.08 ). Firstly, $\mathrm{H}_{3} \mathrm{PO}_{4}$ was added to deionized water, followed by $\mathrm{CuO}$ at $80^{\circ} \mathrm{C}$ while stirring until dissolved completely. And then, $\mathrm{Al}(\mathrm{OH})_{3}$, silica gel, morpholine, and HF were added. The initial gel was loaded into the stainless reaction kettles equipped with a polytetrafluorethylene liner of $200 \mathrm{~mL}$ and crystallized for $72 \mathrm{~h}$ at $190^{\circ} \mathrm{C}$. The product was washed and then calcined. Finally, the Cu/SAPO-34 catalysts were obtained. And the preparation method had been described in our previous paper [22].

The Pd modified Cu/SAPO-34 catalysts were prepared with pore volume impregnation. The details were as follows: the $\mathrm{Cu} / \mathrm{SAPO}-34$ catalysts were impregnated by $\mathrm{Pd}\left(\mathrm{NO}_{3}\right)_{2}$ solution $(1 \mathrm{~mol} / \mathrm{L})$ overnight to give a $0.5 \% \mathrm{Pd}$ loading, and then dried at $120^{\circ} \mathrm{C}$ and calcined at $600^{\circ} \mathrm{C}$ for $3 \mathrm{~h}$.

2.2. Characterization. The XRD patterns of powder samples were obtained on a Japanese Rigaku D/MAX2500 diffractometer at $45 \mathrm{kV}$ and $100 \mathrm{~mA}$ with $\mathrm{CuK} \alpha$ radiation $(\lambda=$ $0.154 \mathrm{~nm})$. The scanning rate and range were $8^{\circ} / \mathrm{min}$ and $5^{\circ}-$ $85^{\circ}$, respectively.

The SEM images were obtained by a Japanese Jeol Jsm$6700 \mathrm{~F}$ at $10 \mathrm{kV}$. The samples were covered with a thin gold layer before scanning.

The $\mathrm{Cu}$ content was measured using an atomic absorption spectroscopy (AAS; Varian AA240FS, USA) with a $324.7 \mathrm{~nm}$ $\mathrm{Cu}$ testing wavelength, operating at $3.0 \mathrm{~mA}$ lamp current and a fuel gas of $\mathrm{C}_{2} \mathrm{H}_{2}(1700 \mathrm{~mL} / \mathrm{min})$.

2.3. Activity and Antiaging Capacity Test. The activities of the $\mathrm{Cu} / \mathrm{SAPO}-34$ catalysts for the selective catalytic reduction (SCR) of $\mathrm{NO}_{x}$ by $\mathrm{C}_{3} \mathrm{H}_{6}$ or $\mathrm{NH}_{3}$ at atmospheric pressure were determined using a fixed-bed flow microreactor. The devices were composed of a gas-way equipped with a flow controller, fixed-bed quartz reactor $(\Phi=8.5 \mathrm{~mm})$, a temperature controller, and a detection system. A total flow rate of $100 \mathrm{~mL} / \mathrm{min}$ was used for the catalytic activity runs. The feed gas consisted of $0.6 \% \mathrm{NO}, 0.6 \% \mathrm{C}_{3} \mathrm{H}_{6}$ or $0.6 \% \mathrm{NH}_{3}$, and $5 \%$ $\mathrm{O}_{2}$ with $\mathrm{He}$ as the balance gas. The catalyst powder (40-60 mesh) was placed into the center of the quartz reactor.

Firstly, He gas flow of $100 \mathrm{~mL} / \mathrm{min}$ was used to sweep off for $2 \mathrm{~h}$ in order to eliminate the $\mathrm{N}_{2}$ residue in the reactor and then switched to the simulated exhaust. The reactor was heated up to $50^{\circ} \mathrm{C}$, holden for $0.5 \mathrm{~h}$, and then risen to $600^{\circ} \mathrm{C}$ at a rate of $7^{\circ} \mathrm{C} / \mathrm{min}$. $\mathrm{NO}, \mathrm{NO}_{2}, \mathrm{O}_{2}$, and $\mathrm{C}_{3} \mathrm{H}_{6}$ in the gases before and after the catalytic reaction were analyzed simultaneously online by gas chromatograph (GC-9890A, Shanghai Linghua Instrument Company Limited) equipped with column Porapak $Q$ for separating $\mathrm{N}_{2} \mathrm{O}$ and $\mathrm{CO}_{2}$ and column molecular sieve $5 \mathrm{~A}$ for separating $\mathrm{N}_{2}, \mathrm{O}_{2}$ and $\mathrm{CO}$.
The aging treatment is also carried out using the abovementioned fixed-bed flow microreactor. Catalyst samples were exposed to a stream of gases containing $0.03 \% \mathrm{SO}_{2}$ and $10 \%$ vapor balanced with Ar with the total rate of $400 \mathrm{~mL} / \mathrm{min}$ at the temperature of $720^{\circ} \mathrm{C}$ for $10 \mathrm{~h}$. Then, the same way as described above was used to test the aged catalyst activity.

NO conversion was calculated using the following equation:

$$
X=\frac{\left(c_{1}-c_{0}\right)}{c_{1}} \times 100 \% \text {, }
$$

where $X$ is the conversion of $\mathrm{NO}$ and $c_{1}$ and $c_{0}$ are the concentrations of $\mathrm{NO}_{x}\left(\mathrm{NO}, \mathrm{NO}_{2}\right.$, and $\left.\mathrm{N}_{2} \mathrm{O}\right)$ before and after the reaction, respectively.

\section{Results and Discussion}

3.1. Effect of $\mathrm{Cu}$ Content on NO Conversion. The NO conversions over the $\mathrm{Cu} / \mathrm{SAPO}-34$ catalysts with different $\mathrm{Cu}$ contents were investigated using $\mathrm{C}_{3} \mathrm{H}_{6}$ and $\mathrm{NH}_{3}$ as the reductant. The $\mathrm{Cu}$ content can be represented by the $\mathrm{Cu} / \mathrm{Si}$ atom ratio of the crystallization gel. In this paper, the $\mathrm{Cu} / \mathrm{Si}$ atom ratios included 0 (without $\mathrm{Cu}$ ), $0.025,0.05,0.1,0.2$, and 0.4 .

The NO conversions of the Cu/SAPO-34 catalysts with different $\mathrm{Cu} / \mathrm{Si}$ atom ratios are shown in Figure 1 ((a): $\mathrm{C}_{3} \mathrm{H}_{6}$ SCR and (b): $\mathrm{NH}_{3}-\mathrm{SCR}$ ). When the reductant was $\mathrm{C}_{3} \mathrm{H}_{6}$, the $\mathrm{NO}$ conversions of all catalysts were below $70 \%$ in the temperature range of $100-600^{\circ} \mathrm{C}$; Particulary, that of the catalyst without $\mathrm{Cu}$ was below $20 \%$. It can be also seen that the $\mathrm{NO}$ conversions of the catalysts with $\mathrm{Cu} / \mathrm{Si}$ atom ratios 0.05 , 0.1 of and 0.2 were higher than these with $\mathrm{Cu} / \mathrm{Si}$ atom ratios of 0.025 and 0.4 . The $\mathrm{NO}$ conversions of all $\mathrm{Cu} / \mathrm{SAPO}-34$ catalysts increased as the temperature increases from $100^{\circ} \mathrm{C}$ to $600^{\circ} \mathrm{C}$. Moreover, the $\mathrm{NO}$ conversions of all $\mathrm{Cu} / \mathrm{SAPO}-$ 34 catalysts increased sharply at low temperature, while it increased slowly at high temperature.

When the reductant was $\mathrm{NH}_{3}$, the $\mathrm{NO}$ conversions of all catalysts were much higher than using $\mathrm{C}_{3} \mathrm{H}_{6}$ as the reductant in the temperature range of $100-600^{\circ} \mathrm{C}$. Particulary, at $600^{\circ} \mathrm{C}$, the $\mathrm{NO}$ conversions of the $\mathrm{Cu} / \mathrm{SAPO}-34$ catalysts can reach to about $96 \%$ using $\mathrm{NH}_{3}$ as the reductant, while it only reached $65 \%$ using $\mathrm{C}_{3} \mathrm{H}_{6}$ as the reductant. In addition, like $\mathrm{C}_{3} \mathrm{H}_{6}$, the $\mathrm{NO}$ conversions of the catalysts with $\mathrm{Cu} / \mathrm{Si}$ atom ratios from 0.05 to 0.2 were higher than these with $\mathrm{Cu} / \mathrm{Si}$ atom ratios of 0.025 and 0.4 .

On the basis of the above results, it can be concluded that as the $\mathrm{Cu} / \mathrm{Si}$ atom ratios of the crystallization gel were in the range of $0.05-0.2$, the de- $\mathrm{NO}_{x}$ activity of the $\mathrm{Cu} / \mathrm{SAPO}-34$ catalysts was better than others.

The XRD patterns of the Cu/SAPO-34 catalysts with different $\mathrm{Cu}$ contents are shown in Figure 2. It can be obviously found that all samples have SAPO-34 characteristic peaks around $2 \theta=9.45^{\circ} \sim 9.65^{\circ}, 16.0^{\circ} \sim 16.2^{\circ}, 17.85^{\circ} \sim 18.15^{\circ}, 20.55^{\circ} \sim$ $20.9^{\circ}, 24.95^{\circ} \sim 25.4^{\circ}$, and $30.5^{\circ} \sim 30.7^{\circ}$, indicating that SAPO34 was successfully formed using in-situ hydrothermal synthesis. As the $\mathrm{Cu}$ content increases, the peaks position of all the samples do not change. It indicates that the amount of 


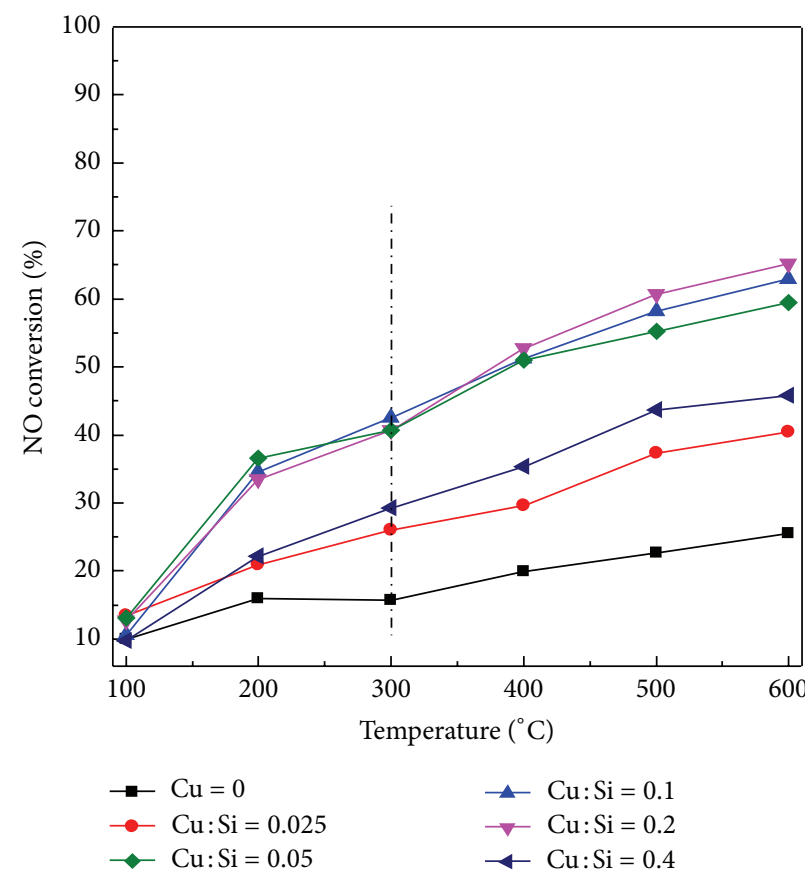

(a) $\mathrm{C}_{3} \mathrm{H}_{6}-\mathrm{SCR}$

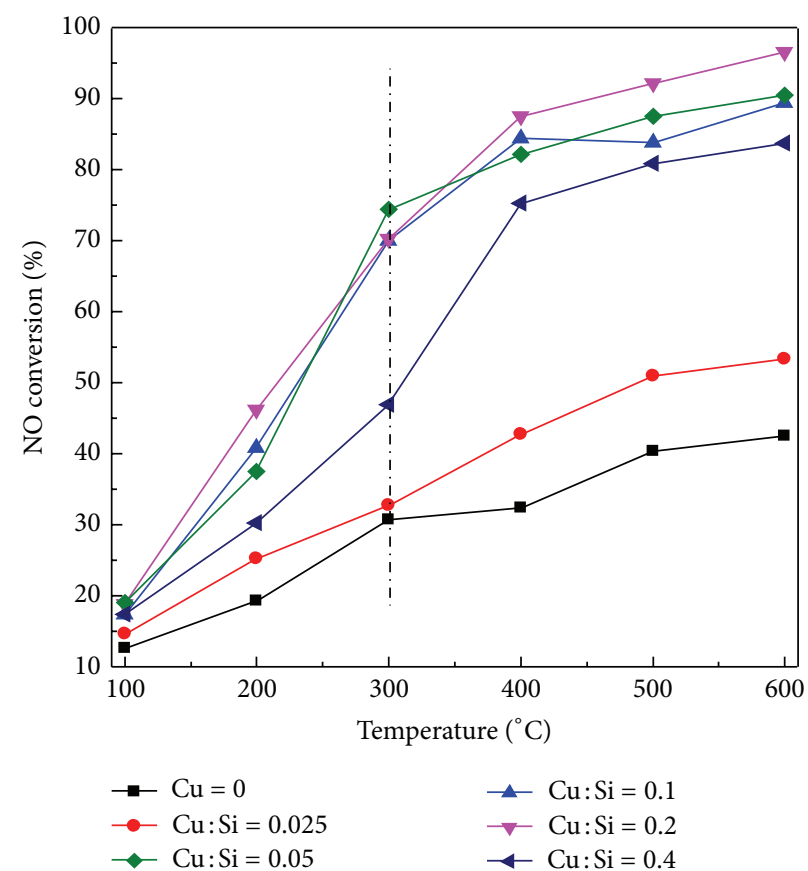

(b) $\mathrm{NH}_{3}-\mathrm{SCR}$

FIGURE 1: Effect of the Cu contents of crystallization gel of Cu/SAPO-34 on NO conversion (GHSV: 10,000 $\mathrm{h}^{-1}$ ).

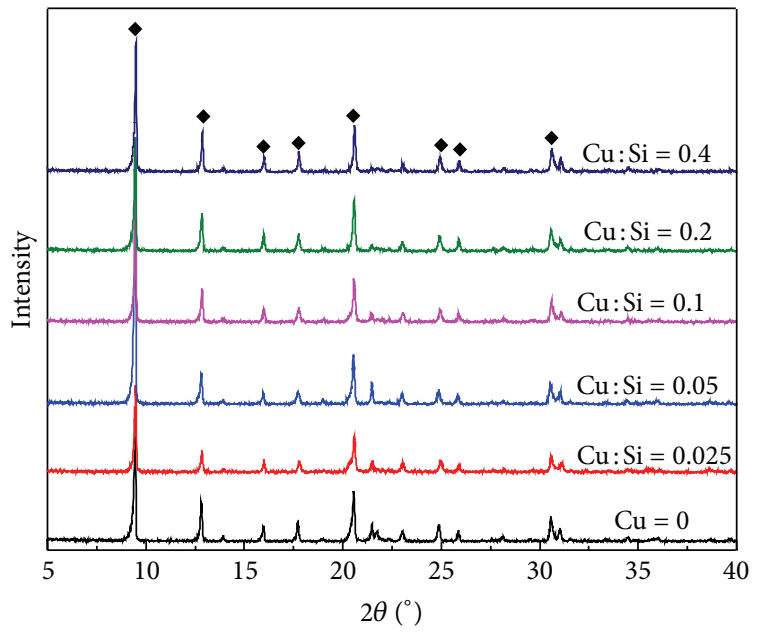

- SAPO-34

FIGURE 2: XRD patterns of SAPO-34 catalysts with different $\mathrm{Cu}$ contents in the crystallization gel.

$\mathrm{Cu}$ content has no effect on the CHA structure of SAPO34. Besides, it should be noted that the peaks became higher and sharper as the SAPO-34 was modified by $\mathrm{Cu}$ because the introduction of $\mathrm{Cu}$ into the framework could reduce the crystal defects and increase the crystallinity [23-26]. It is also found that no peaks related to $\mathrm{CuO}$ and $\mathrm{Cu}_{2} \mathrm{O}$ species appeared in the XRD spectrum of catalyst, indicating that the $\mathrm{Cu}$ loadings were low or the $\mathrm{Cu}$ species were not big enough to be detected [27, 28].

The SEM images of the Cu/SAPO-34 catalysts with different $\mathrm{Cu}$ contents are displayed in Figure 3. The morphology features of the $\mathrm{Cu} / \mathrm{SAPO}-34$ catalysts with different
$\mathrm{Cu}$ contents were compared with those without $\mathrm{Cu}$. It can be found that all the samples were cubic crystals with similar averaged sizes $(0.6-2 \mu \mathrm{m})$, which suggested that the addition of $\mathrm{Cu}$ did not change the $\mathrm{CHA}$ structure and crystal morphology of SAPO-34. It is consistent with the XRD results. When the $\mathrm{Cu} / \mathrm{Si}$ atom ratios were 0 and 0.025 , there was no random-shaped material around the cubic crystals. Some random-shaped materials appeared as the $\mathrm{Cu}$ content in $\mathrm{Cu} / \mathrm{SAPO}-34$ catalysts increased. When the $\mathrm{Cu} / \mathrm{Si}$ atom ratio was 0.2 , the surface of the crystals was nearly covered with the random-shaped material. When the $\mathrm{Cu} / \mathrm{Si}$ atom ratio was 0.4 , big cubic SAPO-34 crystals were formed with the random-shaped material. It should be noted that the relative crystallinity of all the samples was above $92 \%$ (Table 1). It means that the random-shaped material was not copper oxide and they could be SAPO-34 crystals with different crystal morphologies. Thus, it can be deduced that the high $\mathrm{Cu}$ content could change the morphology of SAPO-34 crystal.

For clarifying the effect of different $\mathrm{Cu}$ contents in $\mathrm{Cu} / \mathrm{SAPO}-34$ explicitly, the physical properties of samples are summarized in Table 1 . It is notable that the $\mathrm{Cu} / \mathrm{Si}$ atom ratios of $\mathrm{Cu} / \mathrm{SAPO}-34$ catalysts were quite different from these of precursor solution, but the trend was inconsistent. It indicated that only a part of $\mathrm{Cu}$ could enter into the pore and the skeleton of SAPO-34. In addition, it can be seen from Table 1 that the range of grain sizes of the Cu/SAPO34 catalysts became smaller as the $\mathrm{Cu} / \mathrm{Si}$ ratio increases from 0 to 0.2 . The smaller grain sizes may be beneficial to the catalytic activity. The sample $e(\mathrm{Cu} / \mathrm{Si}=0.2)$ has the highest crystallinity and the smallest grain sizes among the six samples, which is consistent with its high de- $\mathrm{NO}_{x}$ activity. 


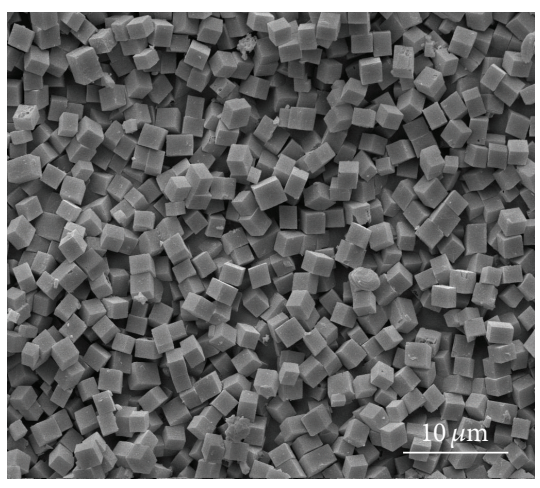

(a)

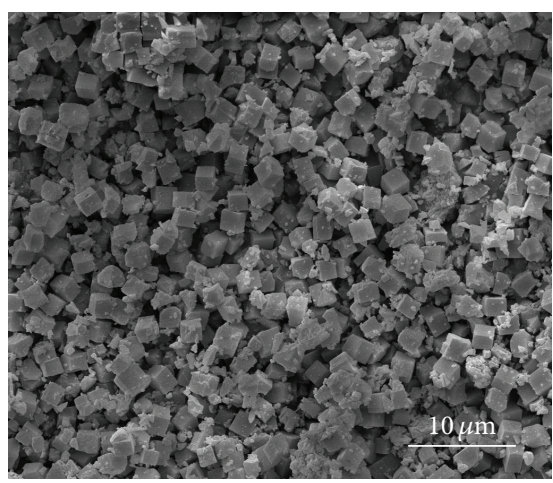

(d)

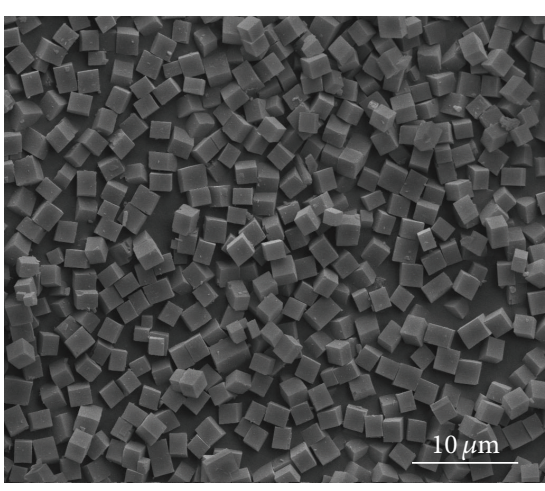

(b)

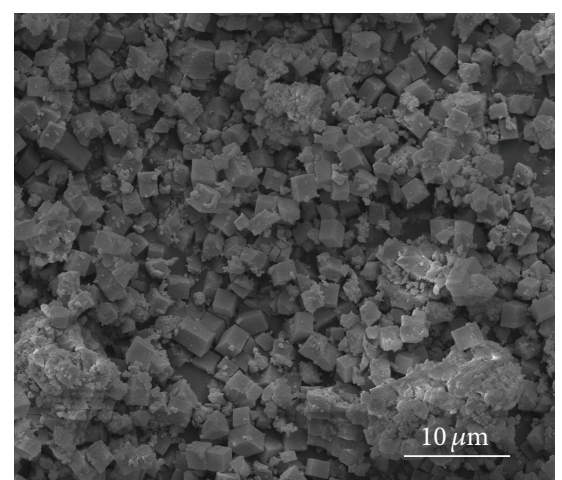

(e)

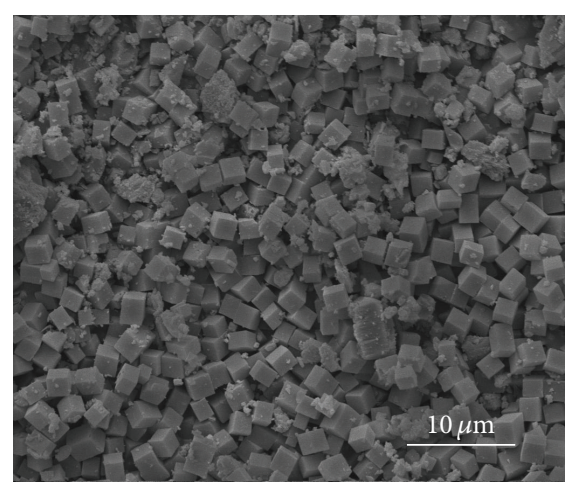

(c)

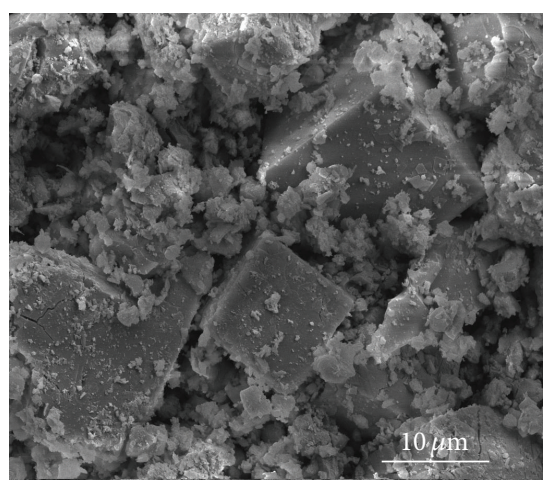

(f)

Figure 3: SEM images of Cu/SAPO-34 catalysts with different $\mathrm{Cu}$ contents $((\mathrm{a}): \mathrm{Cu} / \mathrm{Si}=0,(\mathrm{~b}): \mathrm{Cu} / \mathrm{Si}:=0.025,(\mathrm{c}): \mathrm{Cu} / \mathrm{Si}=0.05,(\mathrm{~d}): \mathrm{Cu} / \mathrm{Si}=$ $0.1,(\mathrm{e}): \mathrm{Cu} / \mathrm{Si}=0.2$, and $(\mathrm{f}): \mathrm{Cu} / \mathrm{Si}=0.4)$.

TABle 1: Physical properties of the Cu/SAPO-34 catalysts with different $\mathrm{Cu}$ contents.

\begin{tabular}{|c|c|c|c|c|c|c|}
\hline \multirow{2}{*}{ Physical properties } & \multicolumn{6}{|c|}{ Samples } \\
\hline & $\mathrm{a}$ & $\mathrm{b}$ & c & $\mathrm{d}$ & e & $\mathrm{f}$ \\
\hline $\mathrm{Cu} / \mathrm{Si}$ atom ratio of initial gel & 0 & 0.025 & 0.05 & 0.1 & 0.2 & 0.4 \\
\hline $\mathrm{Cu} / \mathrm{Si}$ atom ratio of $\mathrm{Cu} / \mathrm{SAPO}-34$ & 0 & 0.023 & 0.038 & 0.065 & 0.120 & 0.171 \\
\hline Relative crystallinity \% & 98.36 & 94.21 & 93.81 & 94.83 & 99.65 & 92.18 \\
\hline Grain size/ $\mu \mathrm{m}$ & $0.6-2.0$ & $1.5-2.0$ & $1.2-2.0$ & $0.8-2.0$ & $1.0-1.5$ & $0.6-18$ \\
\hline
\end{tabular}

3.2. Activity Test of Pd Modified Cu/SAPO-34. For further improving the de- $\mathrm{NO}_{x}$ activity of the $\mathrm{Cu} / \mathrm{SAPO}-34$ catalysts, the noble metal $\mathrm{Pd}$ was introduced into the $\mathrm{Cu} / \mathrm{SAPO}-$ 34 catalysts with $\mathrm{Cu} / \mathrm{Si}=0.05$ and 0.2 by impregnated using $\mathrm{Pd}\left(\mathrm{NO}_{3}\right)_{2}$ as precursor. The Pd loading on catalyst was $0.5 \%$ (denoted as $\mathrm{PdCu} / \mathrm{SAPO}-34$ ). Figure 4 illustrates the NO conversions of the PdCu/SAPO-34 catalysts. The experimental GHSV is $40,000 \mathrm{~h}^{-1}$, which is close to the real diesel engine exhaust.

When $\mathrm{C}_{3} \mathrm{H}_{6}$ was used as reducing agent and the temperature was below $300^{\circ} \mathrm{C}$, the $\mathrm{NO}$ conversions of the $\mathrm{PdCu} / \mathrm{SAPO}-34$ catalysts were similar to the samples without $\mathrm{Pd}$. However, when the temperature rises from $300^{\circ} \mathrm{C}$ to $600^{\circ} \mathrm{C}$, the advantage of $\mathrm{Pd}$ became significant. The NO conversions of PdCu/SAPO-34 catalysts were much higher than these of $\mathrm{Cu} / \mathrm{SAPO}-34$ catalysts and it can reach to around $70 \%$. It is also found that the de- $\mathrm{NO}_{x}$ activities of the $\mathrm{PdCu} / \mathrm{SAPO}-34$ catalysts with $\mathrm{Cu} / \mathrm{Si}=0.2$ were superior to these of $\mathrm{Cu} / \mathrm{Si}=0.05$, especially, at the higher temperature.
When $\mathrm{NH}_{3}$ was used as reducing agent, the NO conversions of the $\mathrm{PdCu} / \mathrm{SAPO}-34$ catalysts were similar to those of the $\mathrm{Cu} / \mathrm{SAPO}-34$ catalysts, especially, at the low temperature. The de- $\mathrm{NO}_{x}$ activities of the PdCu/SAPO-34 catalysts with $\mathrm{Cu} / \mathrm{Si}=0.2$ were higher than these with $\mathrm{Cu} / \mathrm{Si}=0.05$, and the maximum of the NO conversion can reach to $90 \%$. That is because the reaction between $\mathrm{NH}_{3}$ and $\mathrm{NO}$ with low activation energy is quite easy [29]. According to the previous reports [30], the ammonium ion would react with the NO$\mathrm{Pd}^{2+}$ species to give $\mathrm{N}_{2}$. Similarly, the activity of the $\mathrm{Pd}$ modified $\mathrm{Cu} / \mathrm{SAPO}-34$ samples was superior to those without $\mathrm{Pd}$, especially, at the high temperature.

\subsection{Antiaging Performance of Catalysts}

3.3.1. Cu/SAPO-34 Catalysts. The effects of aging on the de$\mathrm{NO}_{x}$ activity of the $\mathrm{Cu} / \mathrm{SAPO}-34$ catalysts with $\mathrm{Cu} / \mathrm{Si}=0.2$ and $\mathrm{Cu} / \mathrm{Si}=0.05$ were shown in Figures $4(\mathrm{a})$ and $4(\mathrm{c})$. The $\mathrm{NO}$ conversion of the two kinds of the $\mathrm{Cu} / \mathrm{SAPO}-34$ catalysts 


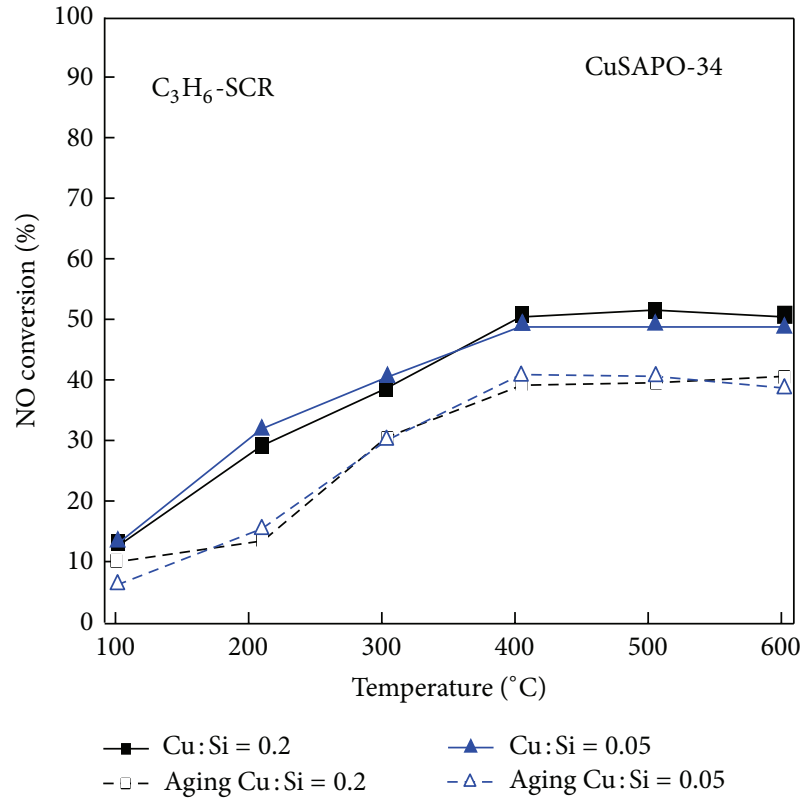

(a)

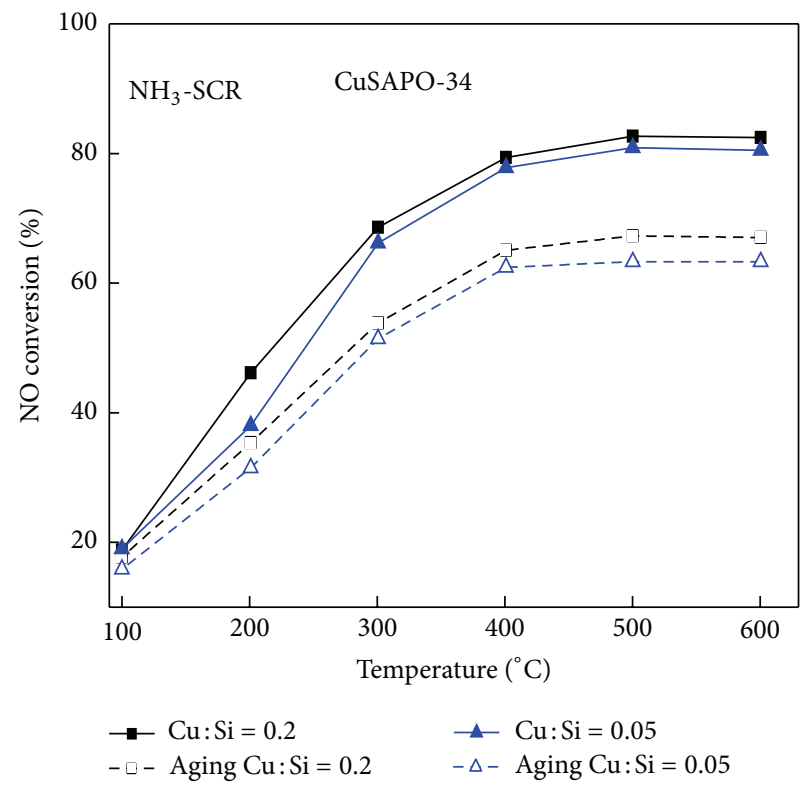

(c)

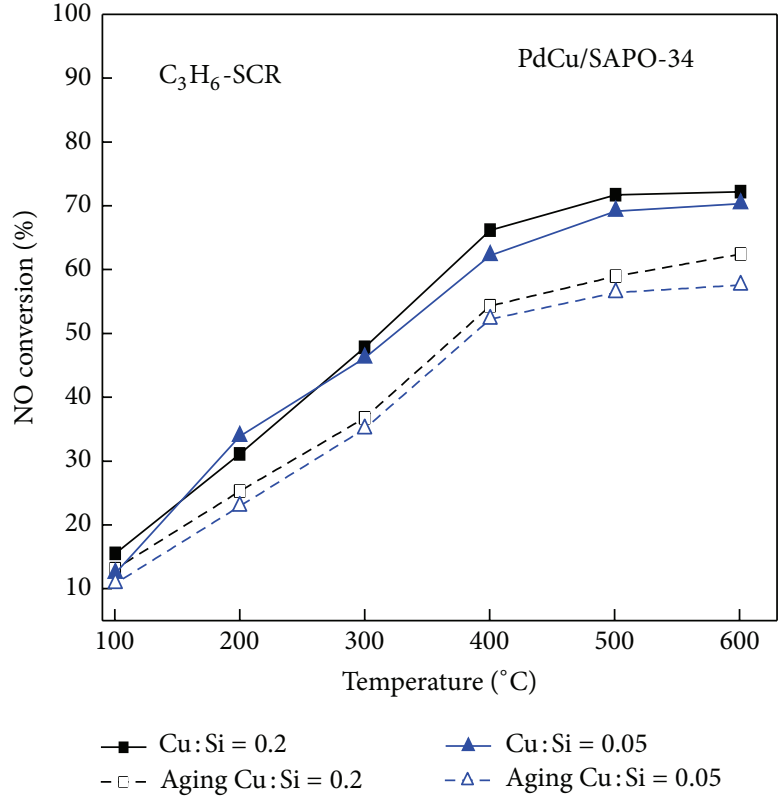

(b)

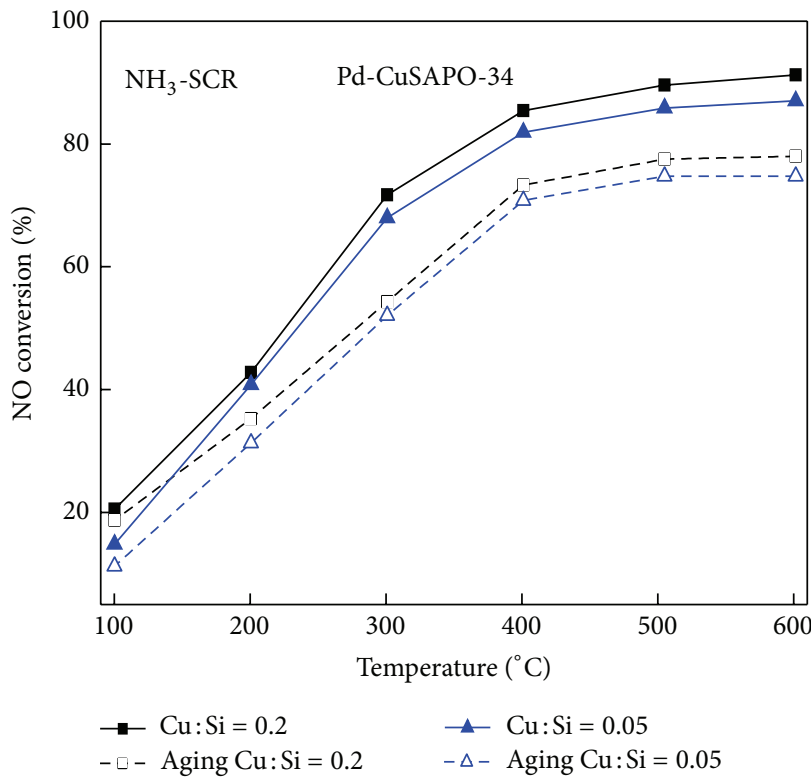

(d)

Figure 4: NO conversion of PdCu/SAPO-34 and Cu/SAPO-34 catalysts (GHSV: 40,000 h ${ }^{-1}$ ).

decreased sharply after aging for $\mathrm{C}_{3} \mathrm{H}_{6}$-SCR, especially, when the temperature is in the range of $200-600^{\circ} \mathrm{C}$. For $\mathrm{NH}_{3}$ SCR, the NO conversions of the two kinds of Cu/SAPO34 catalysts decreased slightly at low temperature, but it decreased significantly as the temperature was above $200^{\circ} \mathrm{C}$, particularly, for the sample with $\mathrm{Cu} / \mathrm{Si}=0.05$.

Figure 5 illustrates the XRD patterns of the $\mathrm{Cu} / \mathrm{SAPO}$ 34 catalysts before and after aging. The intensities of the characteristic peaks weakened after aging compared with the fresh samples, which indicated that the aging process had a negative effect on the crystallinity. It may be the reason for the decrease of the de- $\mathrm{NO}_{x}$ activity.
In order to investigate the effect of aging on the morphology and structure of the $\mathrm{Cu} / \mathrm{SAPO}-34$ catalysts, the samples before and after aging were characterized by SEM and the results are shown in Figure 6. Comparing with the fresh samples, more random-shaped materials were found around the crystal particles; the smooth and regular crystal grains were partly destroyed, which leads to the decrease of the NO conversion of the $\mathrm{Cu} / \mathrm{SAPO}-34$ catalysts.

3.3.2. PdCu/SAPO-34 Catalysts. The activity test of the $\mathrm{PdCu} / \mathrm{SAPO}-34$ catalysts before and after aging in $\mathrm{C}_{3} \mathrm{H}_{6}$ and $\mathrm{NH}_{3}$ is also shown in Figures 4(b) and 4(d). The NO 


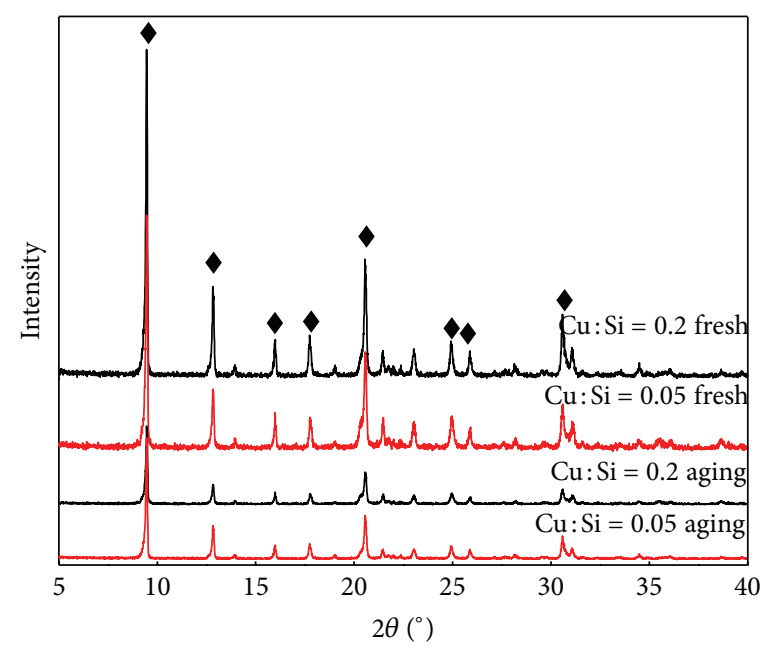

- SAPO-34

FIGURE 5: XRD patterns of Cu/SAPO-34 samples before and after aging.

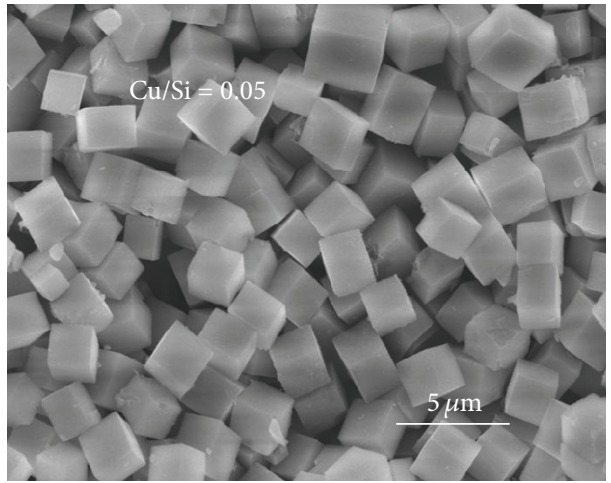

(a)

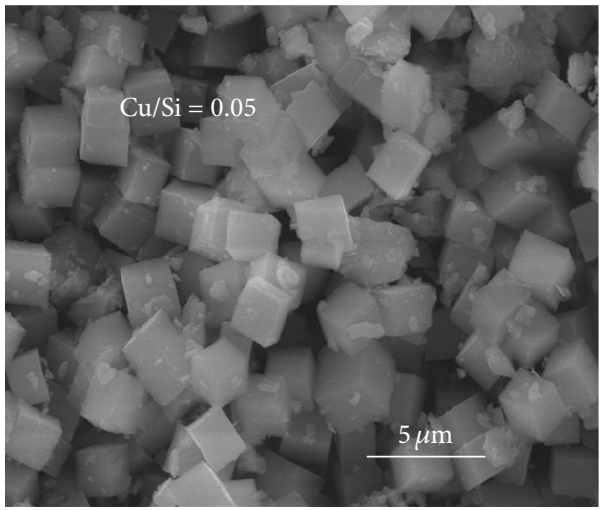

(c)

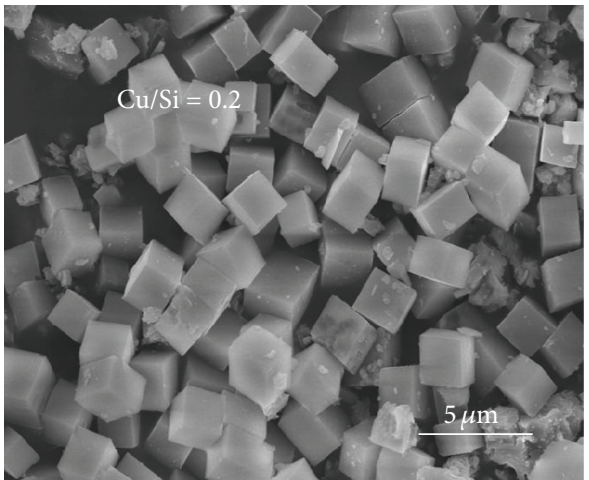

(b)

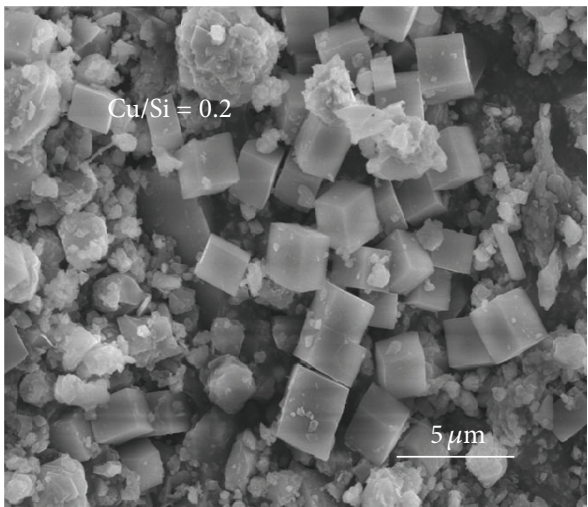

(d)

FIGURE 6: SEM images of Cu/SAPO-34 before ((a) and (b)) and after aging ((c) and (d)).

conversion of the two PdCu/SAPO-34 samples decreased less than the samples without Pd after aging. Besides, the de- $\mathrm{NO}_{x}$ activities of the aged $\mathrm{PdCu} / \mathrm{SAPO}-34$ catalysts were superior to that of the aged $\mathrm{Cu} / \mathrm{SAPO}-34$ catalysts. It indicated that the addition of Pd can improve the antiaging performance of the $\mathrm{Cu} / \mathrm{SAPO}-34$ catalysts.

The XRD patterns of the PdCu/SAPO-34 catalysts are shown in Figure 7. Compared with Figure 1, it can be found that the peaks positions are not remarkably changed by the addition of $\mathrm{Pd}$. No characteristic peak for $\mathrm{Pd}$ was visible, which should be related to the low Pd addition amount. The crystal type was still mainly occupied by the SAPO-34 catalyst. The XRD patterns of the PdCu/SAPO-34 samples after aging treatment are also displayed in Figure 7. The crystalline types of samples before and after aging treatment had no obvious changes and also mainly composed of the SAPO-34 


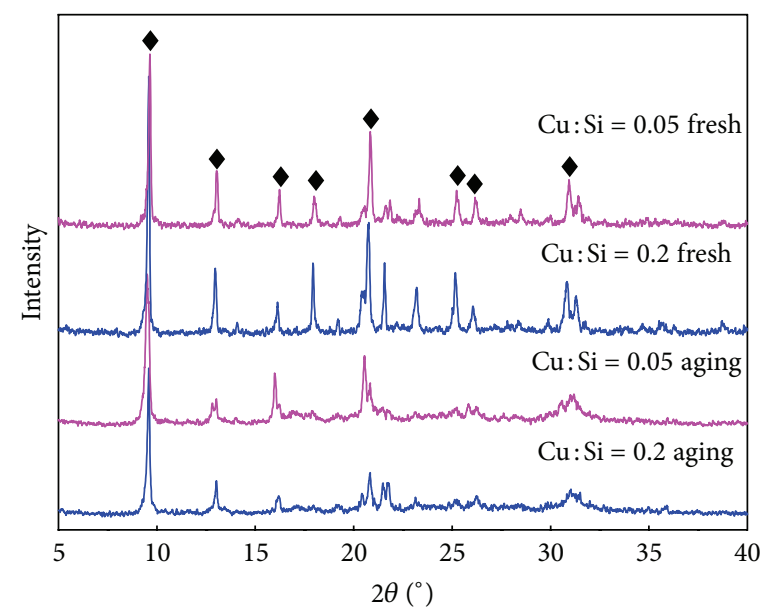

- CuSAPO-34

FIgURE 7: XRD patterns of PdCu/SAPO-34 before and after aging treatment.

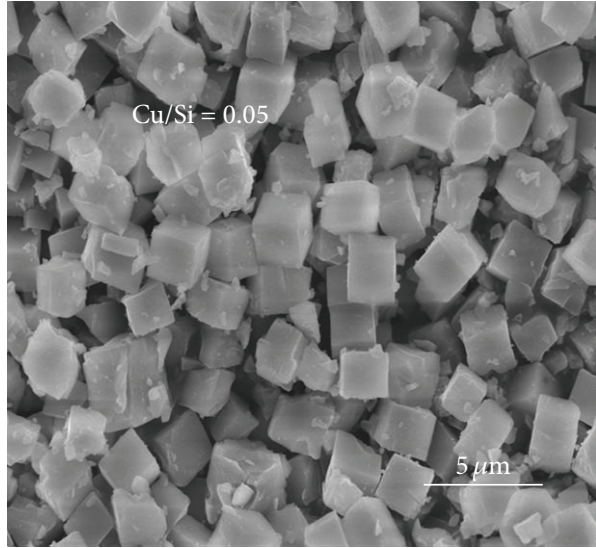

(a)

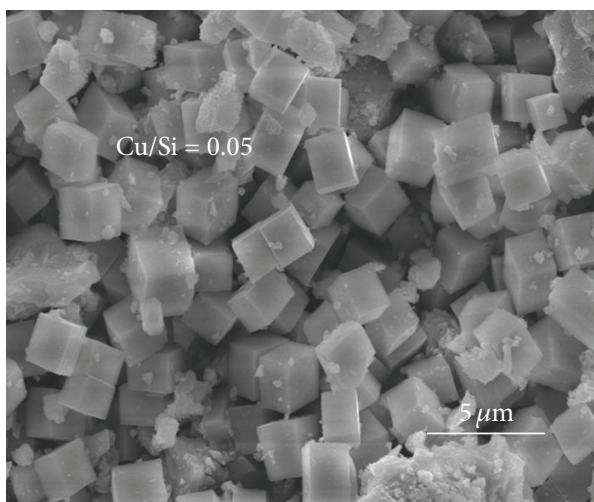

(c)

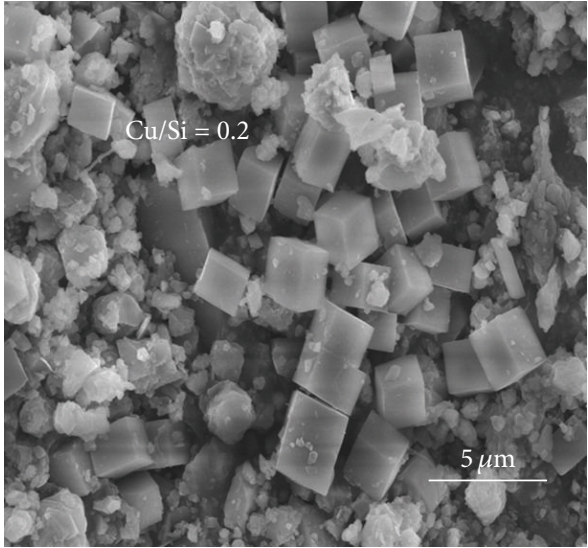

(b)

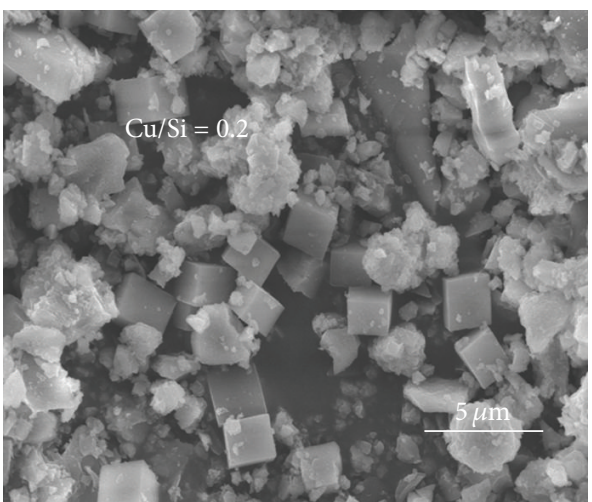

(d)

Figure 8: SEM images of PdCu/SAPO-34 before ((a) and (b)) and after aging ((c) and (d)).

catalyst. However, the peaks intensity of the SAPO-34 catalyst corresponding to $2 \theta=16.0^{\circ} \sim 16.2^{\circ}, 17.85^{\circ} \sim 18.15^{\circ}, 20.55^{\circ} \sim$ $20.9^{\circ}, 24.95^{\circ} \sim 25.4^{\circ}$, and $30.5^{\circ} \sim 30.7^{\circ}$ was weakened obviously, indicating that the aging treatment partially destroyed the regularity and crystallinity of SAPO-34.
The SEM images of the PdCu/SAPO-34 catalyst with $\mathrm{Cu} / \mathrm{Si}=0.05$ and 0.2 are given in Figure 8 . All of the samples were mainly composed of the cubic crystal grains, which were the SAPO-34 crystals surrounded by some randomshaped materials. Comparing with the fresh samples, the 
aged samples had more random-shaped materials which were the fragment of SAPO-34 crystals. It suggested that more SAPO-34 crystals had been broken after aging treatment, which resulted in the decrease of the NO conversion of the $\mathrm{PdCu} / \mathrm{SAPO}-34$ catalysts.

It can be concluded that the de- $\mathrm{NO}_{x}$ activity of the $\mathrm{Cu} / \mathrm{SAPO}-34$ and PdCu/SAPO-34 catalysts had a decrease due to the rupture of SAPO-34 crystals resulted by the aging treatment. But the antiaging performance of $\mathrm{PdCu} / \mathrm{SAPO}-34$ catalysts was better than $\mathrm{Cu} / \mathrm{SAPO}-34$ catalysts.

\section{Conclusions}

The Cu/SAPO-34 catalysts were successfully prepared by insitu hydrothermal synthesis. The results of XRD and SEM analysis indicated that the addition of $\mathrm{Cu}$ does not change the CHA structure of SAPO-34 crystal and the prepared $\mathrm{Cu} / \mathrm{SAPO}-34$ catalysts were cubic crystals with similar averaged sizes $(0.6-2 \mu \mathrm{m})$. But the high $\mathrm{Cu}$ content could change the morphology of the SAPO-34 crystals. The Cu/SAPO-34 catalysts with $\mathrm{Cu} / \mathrm{Si}=0.05,0.1$, and 0.2 had better de- $\mathrm{NO}_{x}$ activities than other $\mathrm{Cu} / \mathrm{SAPO}-34$ and SAPO-34 catalysts.

The antiaging performance of the Cu/SAPO-34 and $\mathrm{PdCu} / \mathrm{SAPO}-34$ catalysts was studied and the experiment results suggested that the de- $\mathrm{NO}_{x}$ activity of the $\mathrm{Cu} / \mathrm{SAPO}-$ 34 and PdCu/SAPO-34 catalysts had a decrease due to the rupture of SAPO-34 crystals resulted by the aging treatment. However, the addition of $\mathrm{Pd}$ could improve the de- $\mathrm{NO}_{x}$ activity and antiaging performance of the catalysts.

\section{Acknowledgments}

The authors gratefully thank NSFC (20906067), CPSF (2011M500543), and the Program for the Top Young Academic Leaders of Higher Learning Institutions of Shanxi for their financial support.

\section{References}

[1] J. N. Armor, "Environmental catalysis," Applied Catalysis B, vol. 1, no. 4, pp. 221-256, 1992.

[2] Y. Kondo, T. Kitada, M. Koike, S. Kawakami, and Y. Makino, "Nitric oxide and ozone in the free troposphere over the western Pacific Ocean," Journal of Geophysical Research, vol. 98, no. 11, pp. 20527-20535, 1993.

[3] R. Impens, "Automotive traffic risks for the environment," in Studies in Surface Science and Catalysis, A. Crucq and A. Frennet, Eds., pp. 11-29, New York, NY, USA, 1987.

[4] H. Bosch, F. J. J. G. Janssen, F. M. G. van den Kerkhof, J. Oldenziel, J. G. van Ommen, and J. R. H. Ross, "The activity of supported vanadium oxide catalysts for the selective reduction of NO with ammonia," Applied Catalysis, vol. 25, pp. 239-248, 1986.

[5] L. Wang, J. R. Gaudet, W. Li, and D. Weng, "Migration of Cu species in Cu/SAPO-34 during hydrothermal aging," Journal of Catalysis, vol. 306, pp. 68-77, 2013.

[6] J. J. Xue, X. Q. Wang, G. S. Qi, J. Wang, M. Q. Shen, and W. $\mathrm{Li}$, "Characterization of copper species over Cu/SAPO-34 in selective catalytic reduction of $\mathrm{NO}_{x}$ with ammonia: relationships between active $\mathrm{Cu}$ sites and de- $\mathrm{NO}_{x}$ performance at low temperature," Journal of Catalysis, vol. 297, pp. 56-64, 2013.

[7] L. Wang, W. Li, G. Qi, and D. Weng, "Location and nature of Cu species in Cu/SAPO-34 for selective catalytic reduction of $\mathrm{NO}$ with $\mathrm{NH}_{3}$," Journal of Catalysis, vol. 289, pp. 21-29, 2012.

[8] H.-X. Liu, Z.-K. Xie, C.-F. Zhang, and Q.-L. Chen, "Synthesis of SAPO-34 molecular sieve using hydrogen fluoride and triethylamine as composite template," Chinese Journal of Catalysis, vol. 16, no. 6, pp. 521-527, 2003.

[9] Z. M. Liu, X. Y. Huang, C. Q. He, Y. Yang, L. X. Yang, and G. Y. Cai, "Thermal and hydrothermal stability of SAPO-34 molecular sieve," Chinese Journal of Catalysis, vol. 17, no. 6, pp. 540-543, 1996.

[10] M. Goepper, F. Goth, L. Delmotte, J. L. Guth, and H. Kessler, "Effect of template removal AMD rehydration on the structure of $\mathrm{AlPO}_{4}$ and $\mathrm{AlPO}_{4}$-based microporous crystalline solids," Studies in Surface Science and Catalysis, vol. 49, pp. 857-866, 1989.

[11] J. C. Wang, Z. Q. Liu, G. Feng, L. P. Chang, and W. R. Bao, "In situ synthesis of CuSAPO-34/cordierite and its selective catalytic reduction of nitrogen oxides in vehicle exhaust: the effect of HF," Fuel, vol. 109, pp. 101-109, 2013.

[12] T. Ishihara, M. Kagawa, F. Hadama, and Y. Takita, "Copper ionexchanged SAPO-34 as a thermostable catalyst for selective reduction of $\mathrm{NO}$ with $\mathrm{C}_{3} \mathrm{H}_{6}$," Journal of Catalysis, vol. 169, no. 1, pp. 93-102, 1997.

[13] F. C. Meunier, R. Ukropec, C. Stapleton, and J. R. H. Ross, "Effect of the silver loading and some other experimental parameters on the selective reduction of $\mathrm{NO}$ with $\mathrm{C}_{3} \mathrm{H}_{6}$ over $\mathrm{Al}_{2} \mathrm{O}_{3}$ and $\mathrm{ZrO}_{2}$-based catalysts," Applied Catalysis B, vol. 30, no. 1-2, pp. 163-172, 2001.

[14] T. Horiuchi, T. Fujiwara, L. Chen, K. Suzuki, and T. Mori, "Selective catalytic reduction of $\mathrm{NO}$ by $\mathrm{C}_{3} \mathrm{H}_{6}$ over $\mathrm{Co} / \mathrm{Al}_{2} \mathrm{O}_{3}$ catalyst with extremely low cobalt loading," Catalysis Letters, vol. 78, no. 1-4, pp. 319-323, 2002.

[15] M. Kantcheva, "FT-IR spectroscopic investigation of the reactivity of $\mathrm{NO}_{x}$ species adsorbed on $\mathrm{Cu}^{2+} / \mathrm{ZrO}_{2}$ and $\mathrm{CuSo}_{4} / \mathrm{ZrO}_{2}$ catalysts toward decane," Applied Catalysis B, vol. 42, no. 1, pp. 89-109, 2003.

[16] D. Pietrogiacomi, D. Sannino, A. Magliano, P. Ciambelli, S. Tuti, and V. Indovina, "The catalytic activity of $\mathrm{CuSO}_{4} / \mathrm{ZrO}_{2}$ for the selective catalytic reduction of $\mathrm{NO}_{x}$ with $\mathrm{NH}_{3}$ in the presence of excess $\mathrm{O}_{2}$," Applied Catalysis B, vol. 36, no. 3, pp. 217-230, 2002.

[17] L. Ma, Y. S. Cheng, G. Cavataio, R. W. McCabe, L. X. Fu, and J. H. $\mathrm{Li}$, "Characterization of commercial Cu-SSZ-13 and Cu-SAPO34 catalysts with hydrothermal treatment for $\mathrm{NH}_{3}-\mathrm{SCR}$ of $\mathrm{NO}_{x}$ in diesel exhaust," Chemical Engineering Journal, vol. 225, pp. 323-330, 2013.

[18] J. H. Kwak, D. Tran, S. D. Burton, J. Szanyi, J. H. Lee, and C. H. F. Peden, "Effects of hydrothermal aging on NH3-SCR reaction over Cu/zeolites," Journal of Catalysis, vol. 287, pp. 203-209, 2012.

[19] F. Diehl, J. Barbier Jr., D. Duprez, I. Guibard, and G. Mabilon, "Catalytic oxidation of heavy hydrocarbons over $\mathrm{Pt} / \mathrm{Al}_{2} \mathrm{O}_{3}$. Influence of the structure of the molecule on its reactivity," Applied Catalysis B, vol. 95, no. 3-4, pp. 217-227, 2010.

[20] L. F. Liotta, "Catalytic oxidation of volatile organic compounds on supported noble metals," Applied Catalysis B, vol. 100, no. 34, pp. 403-412, 2010.

[21] R. J. Farrauto and K. E. Voss, "Monolithic diesel oxidation catalysts," Applied Catalysis B, vol. 10, no. 1-3, pp. 29-51, 1996. 
[22] Y. Q. Zuo, L. N. Han, W. R. Bao, L. P. Chang, and J. C. Wang, "Effect of CuSAPO-34 catalyst preparation method on $\mathrm{NO}_{x}$ removal from diesel vehicle exhausts," Chinese Journal of Catalysis, vol. 34, no. 6, pp. 1112-1122, 2013.

[23] Z. Sarbak and M. Lewandowski, "Catalytic elimination of nitrogen organic compounds from the coal-liquid and structural properties of NiMo catalysts supported on $\mathrm{NaX}$ and $\mathrm{NaY}$ zeolites modified with transition metal cations," Applied Catalysis A, vol. 208, no. 1-2, pp. 317-321, 2001.

[24] T. Armaroli, L. J. Simon, M. Digne et al., "Effects of crystal size and $\mathrm{Si} / \mathrm{Al}$ ratio on the surface properties of H-ZSM-5 zeolites," Applied Catalysis A, vol. 306, pp. 78-84, 2006.

[25] F. Benaliouche, Y. Boucheffa, P. Ayrault, S. Mignard, and P. Magnoux, " $\mathrm{NH}_{3}$-TPD and FTIR spectroscopy of pyridine adsorption studies for characterization of Ag- and $\mathrm{Cu}$-exchanged $\mathrm{X}$ zeolites," Microporous and Mesoporous Materials, vol. 111, no. 13, pp. 80-88, 2008.

[26] Y. X. Wei, D. Z. Zhang, L. Xu et al., "Synthesis, characterization and catalytic performance of metal-incorporated SAPO-34 for chloromethane transformation to light olefins," Catalysis Today, vol. 131, no. 1-4, pp. 262-269, 2008.

[27] L. Huang, F. Peng, H. Wang, H. Yu, and Z. Li, "Preparation and characterization of $\mathrm{Cu}_{2} \mathrm{O} / \mathrm{TiO}_{2}$ nano-nano heterostructure photocatalysts," Catalysis Communications, vol. 10, no. 14, pp. 1839-1843, 2009.

[28] Z. Liu, L. Tang, L. Chang, J. Wang, and W. Bao, "In situ synthesis of Cu-SAPO-34/cordierite for the catalytic removal of $\mathrm{NO}_{x}$ from diesel vehicles by $\mathrm{C}_{3} \mathrm{H}_{8}$," Chinese Journal of Catalysis, vol. 32, no. 4, pp. 546-554, 2011.

[29] I. Mejía-Centeno, S. Castillo, R. Camposeco, and G. A. Fuentes, "SCR of $\mathrm{NO}_{x}$ by $\mathrm{NH}_{3}$ over model catalysts: the kinetic datalinear free energy relation," Catalysis Communications, vol. 31, pp. 11-15, 2013.

[30] K.-I. Shimizu, F. Okada, Y. Nakamura, A. Satsuma, and T. Hattori, "Mechanism of $\mathrm{NO}$ reduction by $\mathrm{CH}_{4}$ in the presence of $\mathrm{O}_{2}$ over Pd-H-mordenite," Journal of Catalysis, vol. 195, no. 1, pp. 151-160, 2000. 

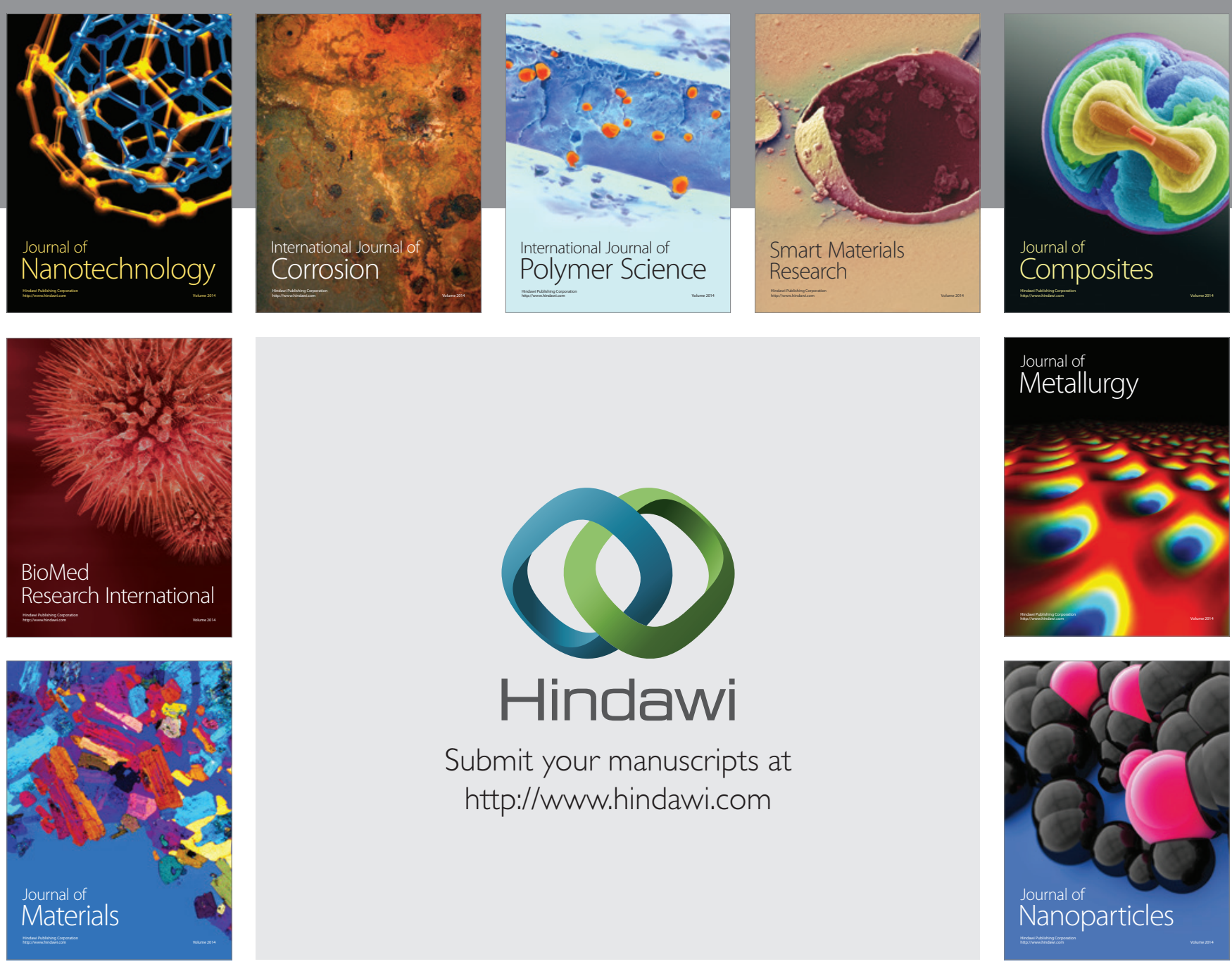

Submit your manuscripts at http://www.hindawi.com
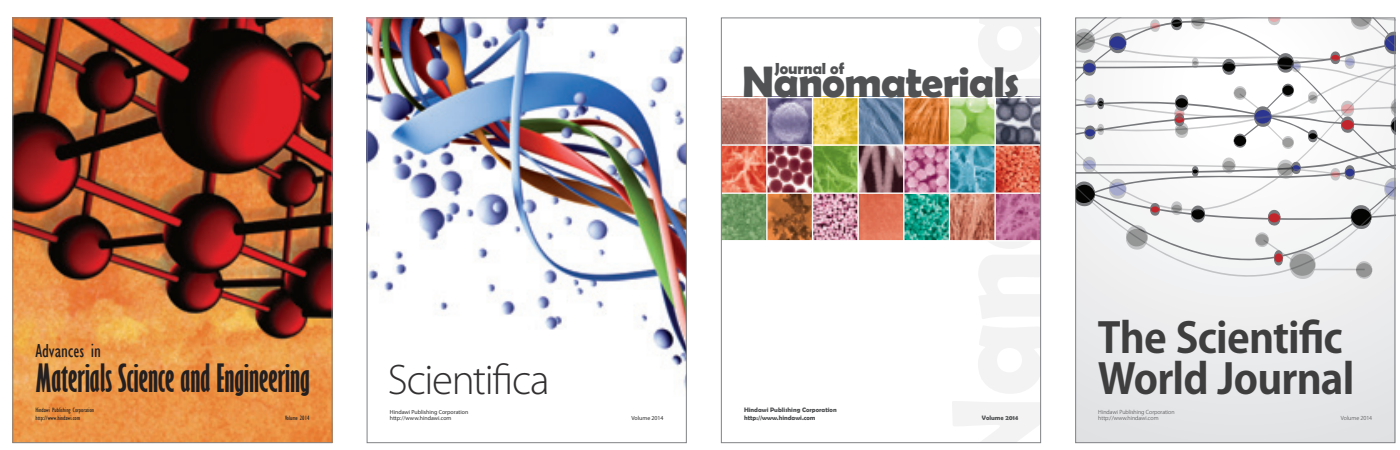

\section{The Scientific World Journal}
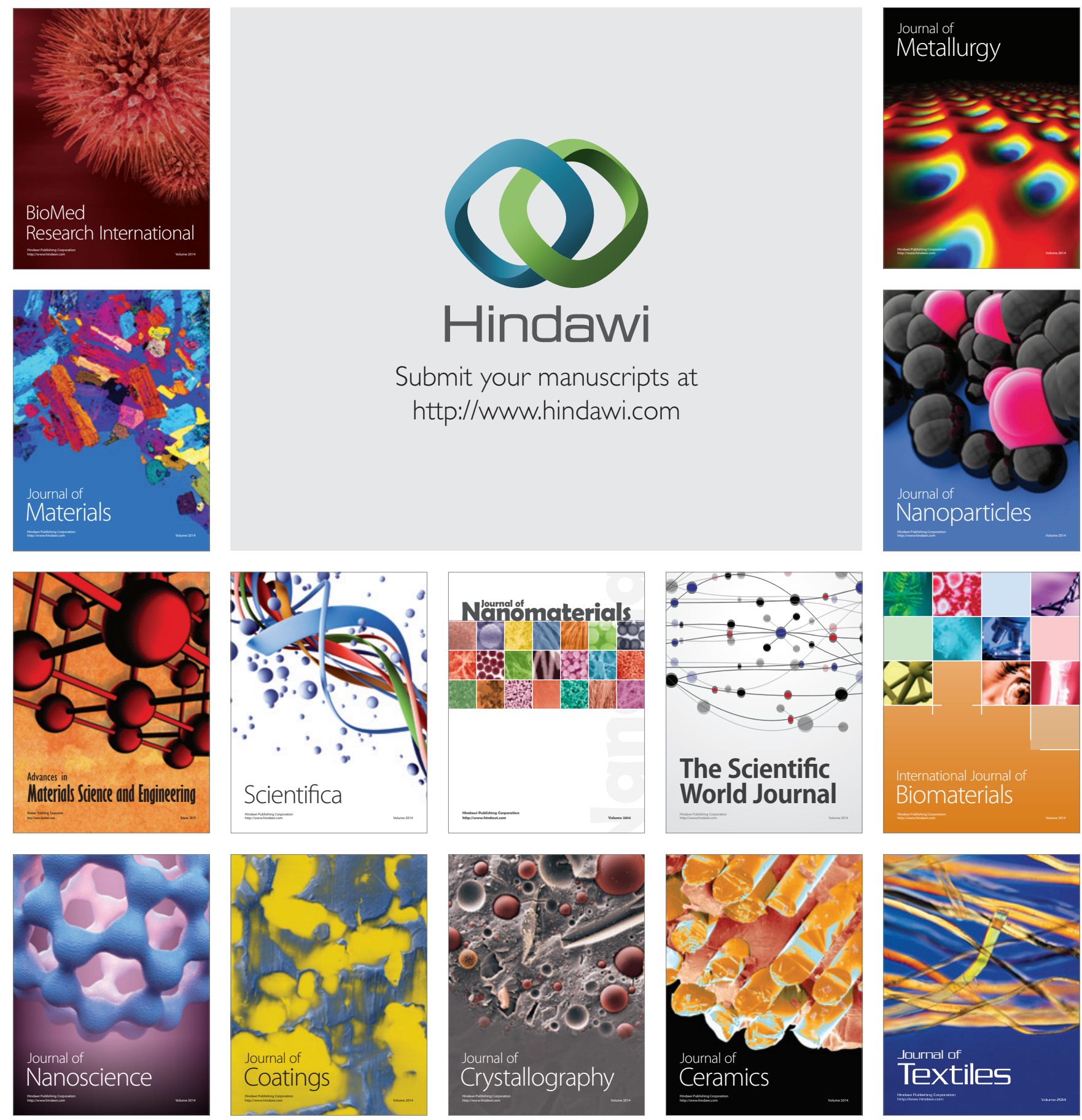